\title{
The Role of University Library in the Campus Culture
}

\author{
Yang Xing \\ Jilin Agricultural University, Changchun 130118, China \\ 37566208@qq.com
}

\begin{abstract}
Campus culture in colleges is the "soft power" in the development of universities. This paper started from the analysis of the essence of campus culture, namely the connotation, content and structure of campus culture, and analyzed the important status and role of University Library in the construction of campus culture. At the same time, under the new situation, according to the higher requirements that campus cultural construction put forward on university, it summed up that the university library not only should have the characteristics of the university library system, but also need to strengthen the collection of cultural and social science books, improve and enrich the quality of service and content, improve the library facilities, create a good study environment etc. and many effective ways to promote the construction of campus culture.
\end{abstract}

Keywords: campus culture; university library; campus cultural construction.

\section{Introduction}

The construction of campus culture is an important part in the teaching of higher education. University library is the information and cultural center, is also the culture communication center and the birthplace of cultural innovation and it's a spirit messenger to guide healthy campus culture. The campus culture, which is created by the teachers and students, embodies the campus spirit of a university, the appearance of the campus, moral standards, values and behavior standards. Its inherent and special cultural atmosphere provides a good environment for the growth of college students.

\subsection{Connotation of Campus Culture}

The campus culture is a kind of unique group culture which grows and develops in the school education environment. It is the embodiment of the overall style of a school. The main body of the campus culture are all the students and teachers and it uses campus as the space, the spirit of the university as a guide, the activities as the main content and it is the sum of material and spiritual wealth jointly created by the interactions in the teaching, scientific research, learning, management, life, entertainment and other fields reflecting the college teachers and students' value orientation, thinking mode and norms of behavior, and it's a sense of community and spiritual atmosphere with campus characteristics and a unique spiritual strength to maintain the group and It is also a school nature, personality and mental outlook reflects [1].

\subsection{Content and Structure of Campus Culture}

The campus culture can be divided into four according to its existing types: material culture, spiritual culture, system culture and behavior culture [2].

(1) Material Culture

Campus material culture refers to the physical environment where the teachers and students are engaged in various activities, mainly refers to the natural environment, campus construction and style, books and reference materials, teaching facilities, cultural facilities, living facilities, campus greening, landscaping, etc. These physical facilities and external environment is the external spirit of the campus, reflecting the cultural connotation of a school. It is the material basis of the campus image and spirit of the campus. Campus material culture can make students unconsciously influenced, inspired and perceived. Beautiful campus environment, can reflect the campus unique ideal, the pursuit and aesthetic taste, and thus naturally form a unique campus atmosphere, and with its internal value concept to motivate, influence people's behavior and ideas. 
(2) Spiritual Culture

Campus spiritual culture is the core and soul of campus culture, is formed gradually in the process of the development of the school which is agreed and voluntary complied by teachers and students and relatively stable, has its own characteristic values, the pursuit of the ideal, moral requirements, norms of behavior, educational philosophy and historical tradition. It's mainly reflected in two aspects, one is cultural form, namely the school campus life, and study, work, entertainment and communication of teachers and the way of thinking and mental state reflected in the activity. The other is cultural morphology, which covers the campus spirit, reflects the tradition and running style including a good classroom atmosphere, strong academic atmosphere, harmonious communication environment. The school motto is the embodiment of campus culture.

(3) System Culture

Campus culture system is campus culture guide to action, is a kind of cultural atmosphere formed by the various rules and regulations formulated by the school sound institutions, good system. It includes the various rules and regulations, moral norms, codes of practice and so on such us some rules and regulations used in order to regulate the management of life and rest of school teachers and students, school management system, enrollment and distribution system and other rules and regulations relating to teaching, research, production. These institutional cultural morphology makes the universities to implement a comprehensive education with purpose, plan and organization and becomes a positive and effective factor to improve and integrate the whole campus culture on college students.

(4) Campus Behavior Culture

The campus behavior culture refers to the various groups of cultural activities and individual cultural behavior the teachers and students engaged in under the standard of the campus spirit culture and the campus system culture. It is the most abundant in content, the most flexible in way, the most obvious in manifestation and the most direct part in campus culture.

Campus system culture is a guide to the campus culture, and it is the intermediary of spiritual culture and material culture. The design and construction of campus material culture, the shaping and identification of campus spiritual culture, the development and implementation of campus system culture are all the result of campus behavior culture [3] .

\section{Role of University Library in the Construction of Campus Culture}

\subsection{University Library is the Second Classroom of College Students}

In 1975 Lyon conference, IFLA (IFLA) defined the function of modern library as: protect the cultural heritage of humanity, develop social education, transfer information science and develop intellectual resources. As for its nature, the exploitation of intellectual resources also belongs to the basic function. It can be seen, the library has important role on the education function. In addition to the class, college students spent most of the time in the library, so the effect on students' growth that the environment, services, and resources of the library play cannot be ignored. After accepting the classroom education, college students can consolidate the knowledge learning on the class in the library, but also they can enrich and supplement their knowledge structure and learn all kinds of documents and materials according to their own interests and profession. The abundant literature information resources of university library is the second classroom that college students must rely on.

\subsection{Spiritual Cultivation of University Library}

Hugo said, "Books are the tools of the soul". Library has created a place to inspire wisdom, cultivate the mind with its quiet and clean reading environment, rich cultural charm of indoor facilities, so that students can be at ease to learn scientific and cultural knowledge. The contained cultural spirit make the human unconsciously accept education, cultivate sentiment, beautify the mind, and thus help to shape their healthy personality and raise overall quality to promote the healthy development of the campus culture. 


\subsection{Entertainment Role of University Library}

Library's own entertainment and leisure functions play more and more important role in the university students' extracurricular cultural life. The establishment of the library new premises provides a comfortable, elegant and spacious, quiet, convenient space for the students' leisure life.

\section{Measures of University Library in the Construction of Campus Culture under New Situation}

(1) Strengthen the construction of literature resources. University library should systematically collect professional and academic development books and periodicals and reference materials based on their own tasks to form a book collection system with the own characteristics. In particular, it should strengthen the collection of social science and cultural books, selection of Chinese ancient classics, Chinese and foreign philosophy, social science and outstanding literary works.

(2) Improve the quality of librarians. University librarians should possess the following qualities: one is good professional ethics with dedication. Second, it is necessary to have good basic skills and a solid professional foundation, high foreign language level and ability of innovation of science and technology. The third is good service skills and infects college students with a good image.

(3) Organize rich and colorful reading activities. The university library should give full play to the advantages to carry out a variety of reading activities and create a strong atmosphere of scholarly campus and play an important role in the construction of campus culture. For example: organize reading month activity, seminars, reading report meeting, reading essay writing, and traditional classics reading and other rich and colorful activities to guide students to correct use of library resources, actively mobilize the students interest in reading, and gradually form a scholarly campus atmosphere and enrich the campus cultural life[4].

(4) Pay attention to the construction of the network environment of the library. Network information has become an important way to affect the society, especially for college students. And the remote user education of digital library is unmatched by any of the traditional library, which is not restricted by time and space. So the construction of network information resources, maintenance, recommendations are very important. Library network information includes not only professional academic resources network database, but also do a good resources navigation and recommendation leading the students to obtain a positive and healthy information and filtering low quality, false and harmful information [5].

\section{Summary}

Campus culture is the spirit and temperament and style of the university and its library collections and services have become a symbol of the development level of colleges. The importance of the role of library in the construction of campus culture is self-evident and how to make full use of the library resources and environmental advantage as well as how to play a more active role in the construction of campus culture to promote the college students' moral construction, cultural construction and cultivate culture, morality, quality, innovative talents are the long term problems the library should think about.

\section{References}

[1] Wang Huijun. The library culture theory [M]. Hunan University press, 2004.

[2] Xie Zheng, Zhou Huiying. The orientation and function of Library in the construction of higher vocational campus culture [J], Education and Occupation, 2008 (18):48-50.

[3] Sun Jie, Yuan Baozhong. Give full play to the university library in the construction of campus culture $[\mathrm{J}]$. Journal of Library and Information Sciences in Agriculture Vol, 21 (12), 2009:153-156. 
[4] Li Qiuxia. The role of university library in the construction of campus culture [J]. China Population, Resources and Environment, 2014: 24 (3):466-467.

[5] Cai-e Liu, Shao Changchen. Role ascertain of university library in the construction of campus culture [J]. Modern intelligence, 2007 (8): 129-130. 